$16^{\text {th }}$ International Conference on

AEROSPACE SCIENCES \& AVIATION TECHNOLOGY,

ASAT - 16 - May 26 - 28, 2015, E-Mail: asat@ mtc.edu.eg

Military Technical College, Kobry Elkobbah, Cairo, Egypt

Tel : +(202) 24025292 - 24036138, Fax: +(202) 22621908

\title{
A Simplified Analytical Method of Shrinkage Stresses on Thick Concrete Walls
}

\author{
A. El-Badawy*
}

\begin{abstract}
Concrete shrinks with time due to the evaporation of moisture in the hardened cement paste. Shrinkage develops more slowly in large members. If shrinkage strains do not develop freely due to restraints, excessive tensile stresses can develop, cause crack and then damage the durability, serviceability and long-term reliability of the structure. The purpose of this study is to present a practical analytical method of thick concrete wall considering shrinkage, thermal cracking and construction sequence. Axial stresses due to shrinkage of thick concrete wall and seasonal temperature loads are calculated using SAP2000 software and CRIRA C660 mathematical model. The CEB-FIP model is used for shrinkage calculation. A case-study for five curved walls is also represented to explain the proposed analysis procedures and applicability.
\end{abstract}

Keywords: shrinkage, thermal cracking, service life, analytical, modeling, codes

\section{Introduction}

The hydration reaction of cement generates a considerable amount of heat during the early stages of hydration with the rate of heat generation reducing with time. The heat generated gradually from the concrete and large concrete sections can develop high temperatures before the rate of heat radiation exceeds the rate of heat generation and concrete begins to cool. The concrete will achieve a maximum temperature in the central area of the pour. The temperature profile will reduce slowly with distance from core until close to the surface, where it will reduce rapidly to the temperature of the environment. Sections with large surface area, such as slabs or thin walls, can lose heat rapidly, while thick sections can take many days to lose heat because of the low thermal conductivity of the concrete and continuing heat development from continuing cement hydration.

Detrimental effects that occur if the concrete temperatures exceed certain values includes: delayed ettringite formation, strength reduction and early-age cracking. Concrete containing fly ash or slag can achieve higher concrete temperature without detriment than concrete using ordinary Portland cement $[1,2]$. These detrimental effects are proportional to temperature so that increased temperature (above the initiation temperature) will increase the detrimental effect.

\footnotetext{
* Assistant Prof. at Thebes Higher Institute of Engineering, Thebes Academy, anwar1_elbadawy@hotmail.com
} 
The temperature reached by concrete during hydration and the differential between the core temperature and the outer concrete is dependent on a variety of factors including: concrete delivery temperature, amount and type of cementitious binder, type of formwork and use of insulation, environmental conditions and conductance of concrete [3]. Numerous computer models have been developed to predict the peak and differential temperatures that may develop within a particular concrete pour.

The expansion and contraction of concrete elements will be restrained either internally within the concrete pour or externally by the surrounding structures. Where the level of restrained strain exceeds the tensile strain capacity of the concrete, cracking will occur. The likelihood that the level of restrained strain may exceed the tensile strain capacity of the concrete is dependent on the following factors: Temperature drop from peak concrete temperature, Coefficient of thermal expansion, Autogenous shrinkage, Level of restraint (internal and external), Creep, Tensile strain capacity and Drying shrinkage.

In the present paper, proposed design process and analysis tools for conducting shrinkage and thermal analysis for a case-study of thick curved concrete walls are presented. A detailed analysis is carried out using CIRIA C660 [4]. Moreover, 3D analysis for long-term shrinkage and seasonal temperature variations is also carried out using SAP2000 and CEB-FIP model [5]. Areas of high stress identified from this analysis and adequate reinforcement provided to limit crack-width to $0.2 \mathrm{~mm}$.

\section{Case Study}

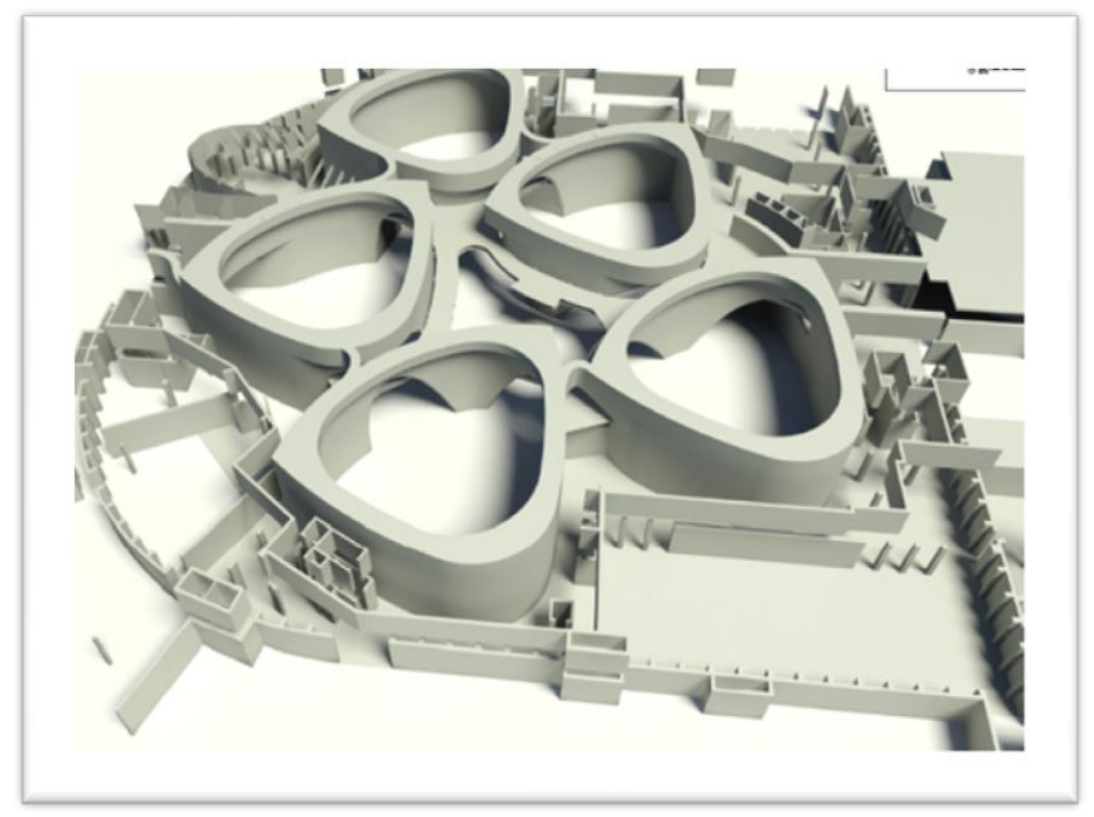

Fig 1 Curved Concrete Walls

Case study for landmark museum project located in Abu-Dhabi, UAE is selected. In this project, there are some challenging elements with unique geometry. A key architectural feature of the building design is a series of five roughly cylindrical $15.75 \mathrm{~m}$ (excluding ring beam) high "Drum" walls of "white' or light colored concrete. Each of the five drums contain approximately 2,500 cubic meters of concrete with a design thickness of $1,000 \mathrm{~mm}$ varying to $3,000 \mathrm{~mm}$ (but mainly $1,500 \mathrm{~mm}$ ) and a surface area of approximately 2,700 square meters. On the top of each of the drum walls there is a massive ring beam ranging in width to $5,000 \mathrm{~mm}$ (to $7,550 \mathrm{~mm}$ in limited locations) with a total volume of approximately 1,500 cubic meters per drum (refer to Fig. 1). The architecture objectives for the curved concrete are: 
a) Special aesthetic concrete feasibilities such as to look like natural white color stone and appear to be carved out on one piece with no joint lines.

b) White cement base, high quality aggregate e.g. white marble or quartz and local UAE white sand.

c) No visible joints between formwork panels and formwork ties for visible areas.

d) No visible rebar spacers.

e) Continuous or semi continuous concrete pour up to the ring beam, possibly poured in layers to limit formwork pressures and concrete supply requirements.

f) Minimization of cracking risk.

A series of four Hot Box trials were conducted to obtain experimental data in relation to the heat gain and likely early age performance of white concrete. The Hot Box dimensions were $1.0 \mathrm{mx} 1.0 \mathrm{~m} \times 1.0 \mathrm{~m}$ and insulated on all sides (including top and bottom) by $100 \mathrm{~mm}$ of polystyrene inside of $18 \mathrm{~mm}$ form ply. The materials used in Hot-box trials were likely to be representative of the concrete to be used in the final project. The temperature is measured in the following locations within each Hot-box: Centre, At the top corner with $75 \mathrm{~mm}$ cover, $75 \mathrm{~mm}$ from the top of the block at the centre of the face, $75 \mathrm{~mm}$ from the side of the block at the centre of the face and Ambient. The temperature results obtained from the four Hot-box trails are given in Table 1. Other results and findings of Hot-box trails have been used as inputs in the present analysis.

Table 1 Summary of Hot-Box Temperature Results

\begin{tabular}{|c|c|l|c|c|c|c|c|}
\hline $\begin{array}{c}\text { Hot- } \\
\text { box }\end{array}$ & $\begin{array}{c}\text { Aggregate } \\
\text { type }\end{array}$ & \multicolumn{1}{c}{$\begin{array}{c}\text { Cement } \\
\text { content }\end{array}$} & $\begin{array}{c}\text { Placing } \\
\text { Temp. }\end{array}$ & $\begin{array}{c}\text { Peak Core } \\
\text { Temp. }\end{array}$ & $\begin{array}{c}\text { Peak } \\
\text { Corner } \\
\text { Temp. }\end{array}$ & $\begin{array}{c}\text { Peak Top } \\
\text { Temp. }\end{array}$ & $\begin{array}{c}\text { Peak } \\
\text { SideTemp. }\end{array}$ \\
\hline 1 & Limestone & $\begin{array}{l}\text { OPC 215 } \\
\text { Slag 215 } \\
\text { Silca fume 20 }\end{array}$ & 29 & 61.8 & 60.3 & 59.3 & 61 \\
\hline 2 & $\begin{array}{l}\text { Iranian } \\
\text { Marble }\end{array}$ & $\begin{array}{l}\text { OPC 215 } \\
\text { Slag 215 } \\
\text { Silca fume 20 }\end{array}$ & 29.2 & 62.5 & $54 / 5$ & 57.1 & 59.5 \\
\hline 3 & $\begin{array}{l}\text { Omani } \\
\text { Marble }\end{array}$ & $\begin{array}{l}\text { OPC 215 } \\
\text { Slag 215 } \\
\text { Silca fume 20 }\end{array}$ & 28.6 & 64.7 & 49.2 & 52.8 & 60.9 \\
\hline 4 & $\begin{array}{l}\text { Omani } \\
\text { Marble }\end{array}$ & $\begin{array}{l}\text { OPC 235 } \\
\text { Slag 235 } \\
\text { Silca fume 20 }\end{array}$ & 27.7 & 65.1 & 52.5 & 57.2 & 61.6 \\
\hline
\end{tabular}

\section{Proposed Design Process}

The proposed design process for the curved walls is outlined in Fig. 2. 

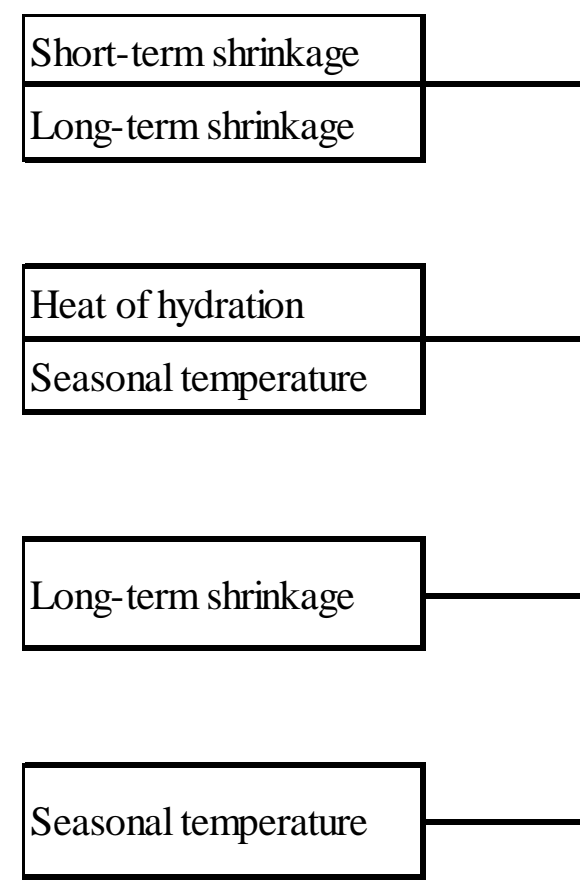

\section{CIRIA C660 Model}

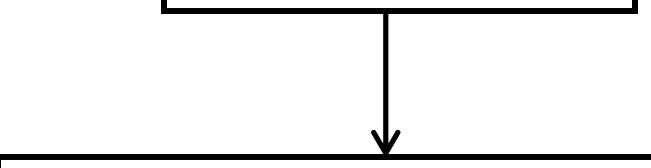

Calculate rebar for the aimed $0.20 \mathrm{~mm}$ crack width

SAP2000 Model

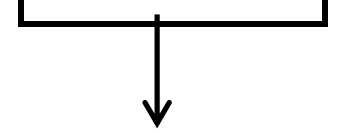

Calculate the required rebar

Fig 2 Proposed Design Process

\section{Classification of Cracking Pattern}

In this section the areas with a high risk of cracking are identified. Figure 3 shows seven different crack types that can be developed in the curved walls due to a combination of edge, end and internal restraints. Table 2 gives the details of these cracks.

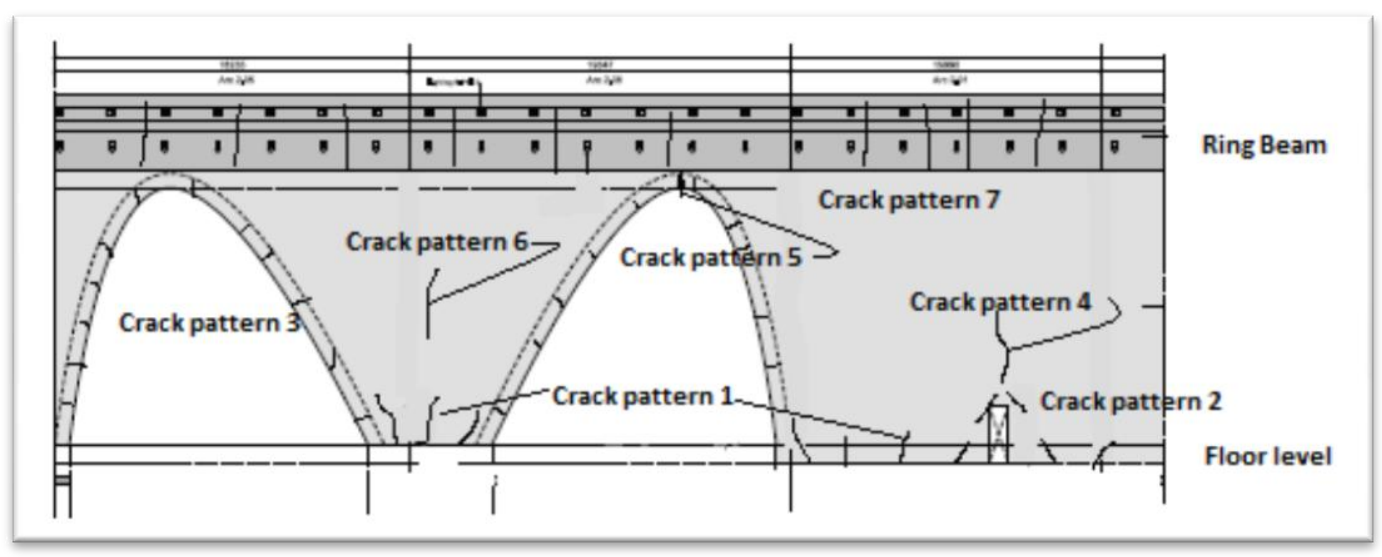

Fig 3 Types of Crack (Developed Front View of Curved Walls) 
Table 2 Types of Cracks Pattern

\begin{tabular}{|c|c|c|}
\hline $\begin{array}{l}\text { Crack } \\
\text { type }\end{array}$ & $\begin{array}{l}\text { Restraint } \\
\text { type }\end{array}$ & Note \\
\hline 1 & Edge & $\begin{array}{l}\text { The level of restraint is influenced by the size of foundation and } \\
\text { height of the exposed wall above the foundation }\end{array}$ \\
\hline 2 & End & $\begin{array}{l}\text { Cracking at re-entrant corners occurs due to stress concentration } \\
\text { similar to that which occurs in end restraint conditions }\end{array}$ \\
\hline 3 & $\begin{array}{l}\text { End and } \\
\text { Internal }\end{array}$ & $\begin{array}{l}\text { The forms used to create the arch will restrain the ends of the } \\
\text { concrete leading to a form of end restraint to the concrete in the } \\
\text { immediate vicinity of the arch }\end{array}$ \\
\hline 4 & End & Similar to re-entrant corners \\
\hline 5 & End & $\begin{array}{l}\text { This is the most critical area of the wall. The arches will tend to } \\
\text { concentrate stress into narrow strip above the arch which will act } \\
\text { as if it is fully restrained at each end }\end{array}$ \\
\hline 6 & Internal & $\begin{array}{l}\text { As the height of the massive base increases the effect of edge } \\
\text { restraint reduces and the effect of internal restraint due to } \\
\text { differential temperature across the thickness of the wall increases }\end{array}$ \\
\hline 7 & Edge/End & The thick ring beam will be restrained by the wall below \\
\hline
\end{tabular}

\section{Predication of Shrinkage Crack Width Using CIRIA C660 Model}

CIRIA C660 mathematical models are used in the calculation of likely crack spacing and crack width for different restraint types during summer and winter conditions. The important input parameters are as follow:

- Age of cracking = 3days

- Creep factor $\mathrm{K} 1=0.65$

- Sustained load factor $\mathrm{K} 2=0.8$

- Coefficient of thermal expansion $=10.60 \mathrm{microstrain} / \mathrm{deg} \mathrm{C}$ (Hot-box results)

- Concrete grade $=55 \mathrm{MPa}$

- Reinforcement yield stress $\mathrm{f}_{\mathrm{y}}=460 \mathrm{MPa}$

- Concrete cover $=50 \mathrm{~mm}$

- Tensile strength of cracking (3days) $=2.43 \mathrm{MPa}$ (Hot-box results)

- Temperature drop for $1500 \mathrm{~mm}$ walls $\mathrm{T} 1=45^{\circ} \mathrm{C}$ in summer conditions and $65^{\circ} \mathrm{C}$ in winter conditions (Hot-box results)

- Temperature drop for $3000 \mathrm{~mm}$ ring beams $\mathrm{T} 1=47^{\circ} \mathrm{C}$ in summer conditions and $59^{\circ} \mathrm{C}$ in winter conditions (Hot-box results)

- Long-term temperature change $\mathrm{T} 2=15^{\circ} \mathrm{C}$

- Drying shrinkage $=200$ microstran (Hot-box results)

The summary of output results for $1500 \mathrm{~mm}$ thick concrete wall in summer conditions is given in Table 3.

Table 3 Summary of Output Results

\begin{tabular}{|c|c|c|c|c|c|c|c|c|}
\hline $\begin{array}{l}\text { Input } \\
\text { Variable }\end{array}$ & \multicolumn{8}{|c|}{1500 mm Thick Wall (Summer Conditions) } \\
\hline $\mathrm{T} 1\left({ }^{\circ} \mathrm{C}\right)$ & \multicolumn{3}{|c|}{45} & & & & & \\
\hline $\mathrm{T} 2\left({ }^{\circ} \mathrm{C}\right)$ & \multicolumn{3}{|c|}{15} & & & & & \\
\hline$\Delta \mathrm{T}\left({ }^{\circ} \mathrm{C}\right)$ & & & & & & & \multicolumn{2}{|c|}{36} \\
\hline Restraint & \multicolumn{3}{|c|}{ Edge } & \multicolumn{3}{|c|}{ End } & \multicolumn{2}{|c|}{ Internal } \\
\hline \multirow[t]{2}{*}{ Rebar } & Details & $\begin{array}{l}\text { Early } \\
\text { Age } \\
\text { Crack } \\
\text { Width } \\
\text { (mm) }\end{array}$ & $\begin{array}{l}\text { Long } \\
\text { Term } \\
\text { Crack } \\
\text { Width } \\
(\mathrm{mm})\end{array}$ & Details & $\begin{array}{l}\text { Early } \\
\text { Age } \\
\text { Crack } \\
\text { Width } \\
\text { (mm) }\end{array}$ & $\begin{array}{l}\text { Long } \\
\text { Term } \\
\text { Crack } \\
\text { Width } \\
(\mathrm{mm})\end{array}$ & Details & $\begin{array}{l}\text { Early } \\
\text { Age } \\
\text { Crack } \\
\text { Width } \\
\text { (mm) }\end{array}$ \\
\hline & T32-100 & 0.10 & 0.17 & $2 \mathrm{~T} 25-100$ & 0.14 & 0.16 & $\mathrm{~T} 25-200$ & 0.05 \\
\hline
\end{tabular}




\section{3D Analytical Model}

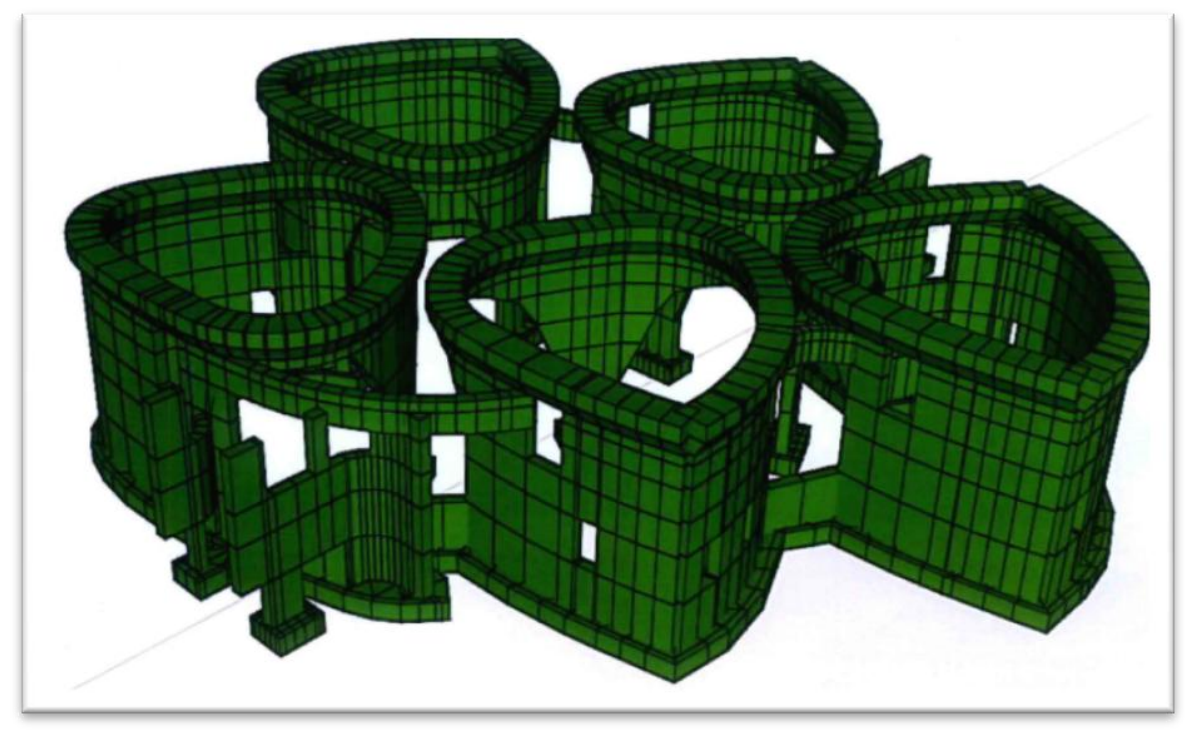

Fig.4 SAP2000 Model 3D View

SAP2000 software is used for shrinkage and seasonal temperature analysis of the curved walls. The walls and ring beams are modeled using thick shell elements (refer to Fig. 4). The CEB-FIP 90 Model Code is used for shrinkage calculation and $\pm 15^{\circ} \mathrm{C}$ seasonal temperature load case is assigned to shell elements. The walls are assumed to be cast separately in four pours as shown in Fig. 5. The duration of the four nonlinear staged construction are 180, 180, 56 and 10950 days. It should be noted that stage one start at time zero days and other stages start at time of end duration of pervious stage. Duration time of stage 4 simulates the longterm state with infinite time. Temperature loads is applied to the SAP model and the analysis results will be used to calculate the reinforcement required. The output results are saved at end of each construction stage.

The other important input parameters are as follow:

- Concrete grade $=55 \mathrm{MPa}$

- Modulus of elasticity $=34 \mathrm{kN} / \mathrm{mm}^{2}$

- Coefficient of thermal expansion $=10.60 \mathrm{microstrain} / \mathrm{deg} \mathrm{C}$ (Hot-box results)

- Relative humidity $=50 \%$

- Notional Size of the member $=0.10 \mathrm{~m}$

- Shrinkage Coefficient $=5$ (Normal and Rapid Hardening Cement)

- Shrinkage start age $=3$ days 


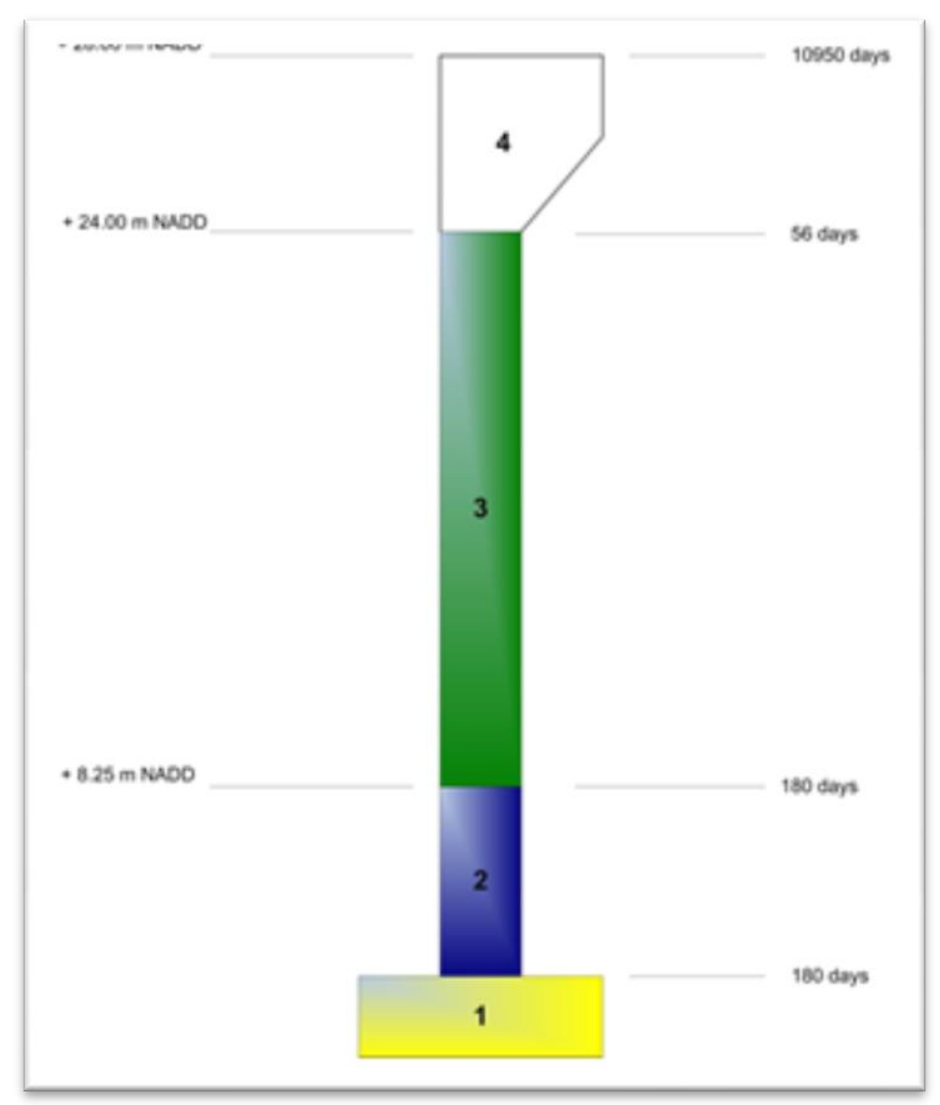

Fig. 5 Proposed Construction Stages

The axial stresses due to shrinkage and/or seasonal temperature variations are obtained from the SAP2000 model at each construction stage. Snap shots of output results are shown in Figs. 6 to 9 . The shell areas with tensile stresses exceed the tensile strength of concrete are identified and adequate reinforcement is provided to limit crack-width to be $0.2 \mathrm{~mm}$.

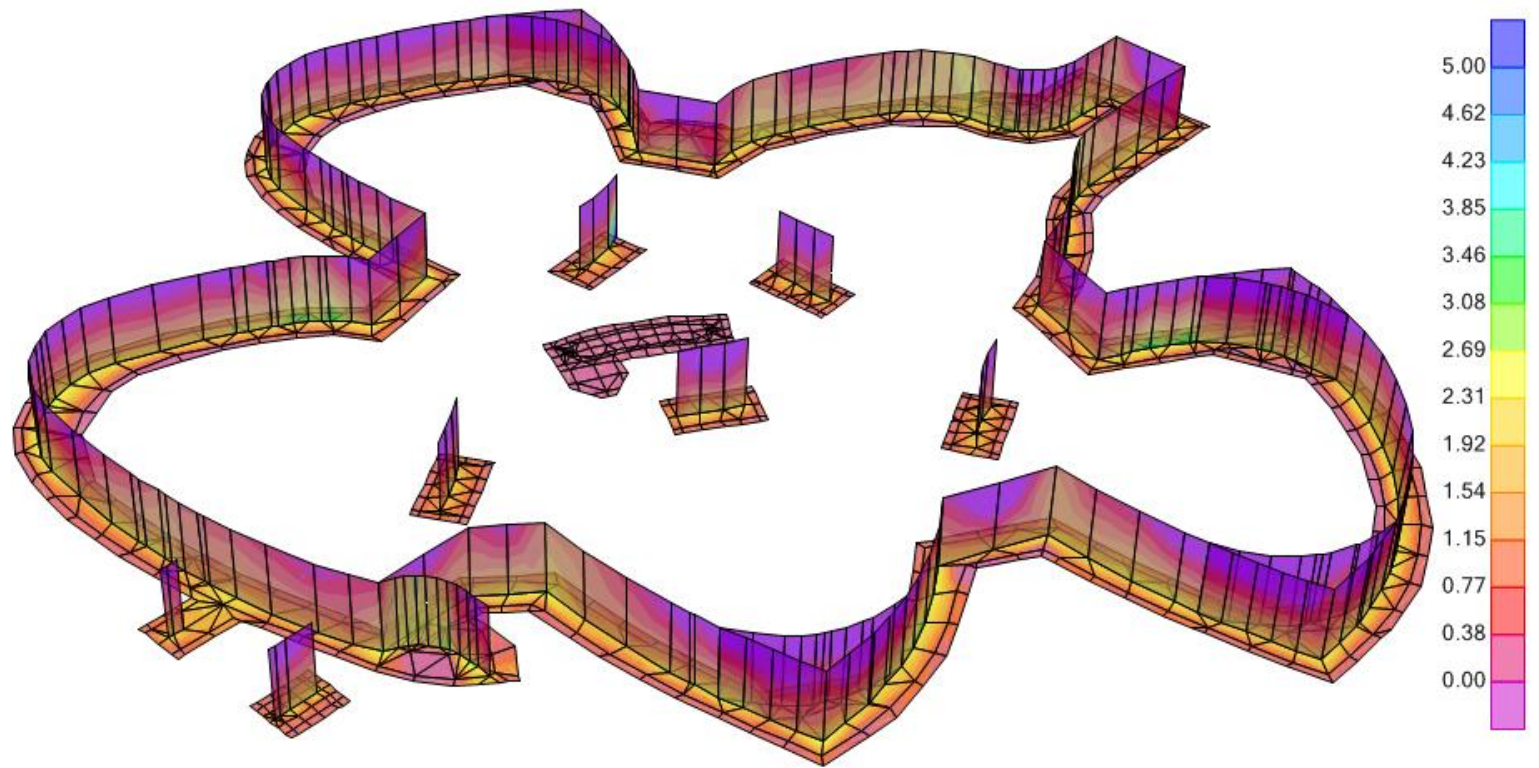

Fig. 6 Maximum Shrinkage Stresses (End of Construction Stage 2) 


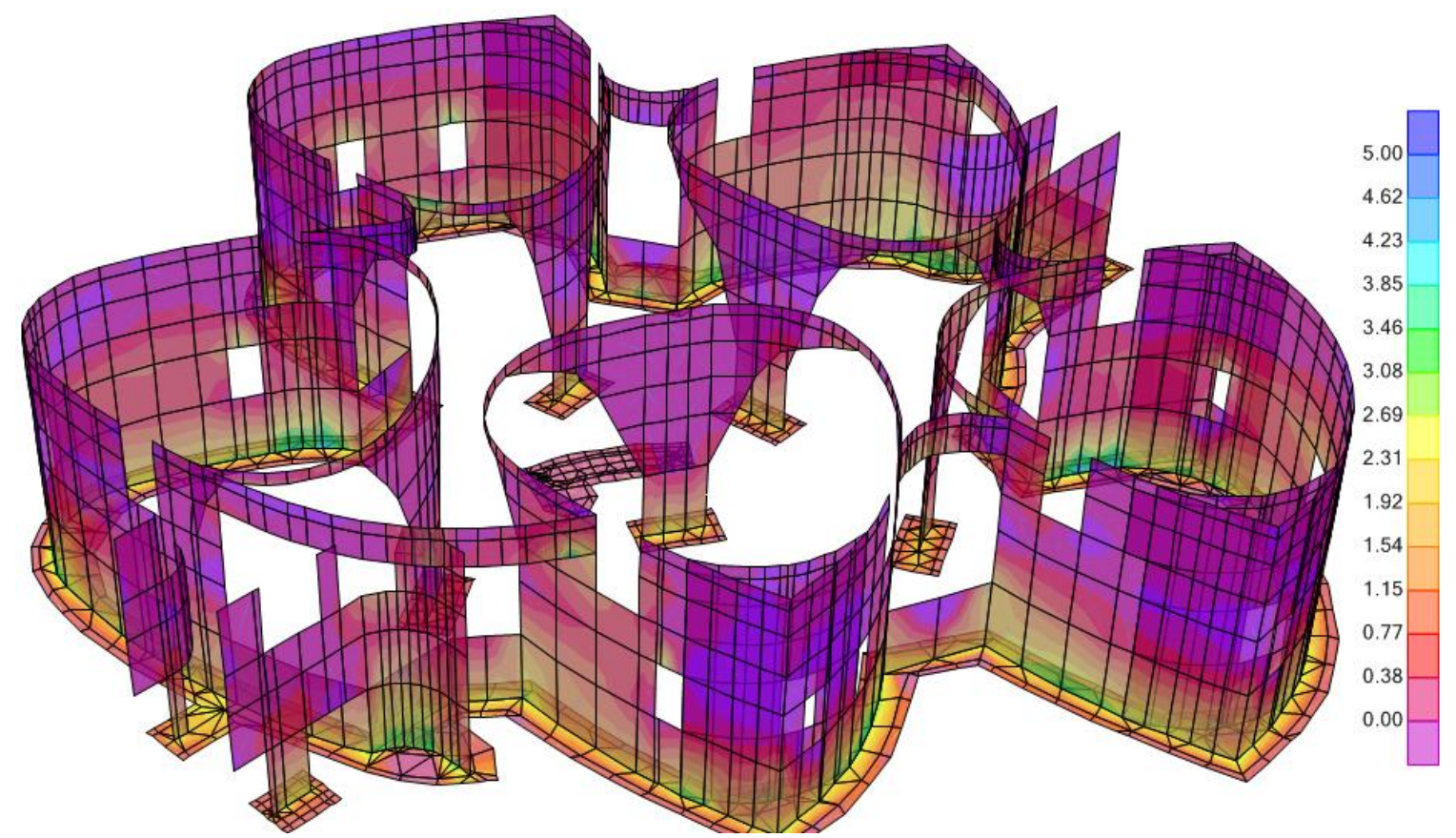

Fig. 7 Maximum Shrinkage Stresses (End of Construction Stage 3)

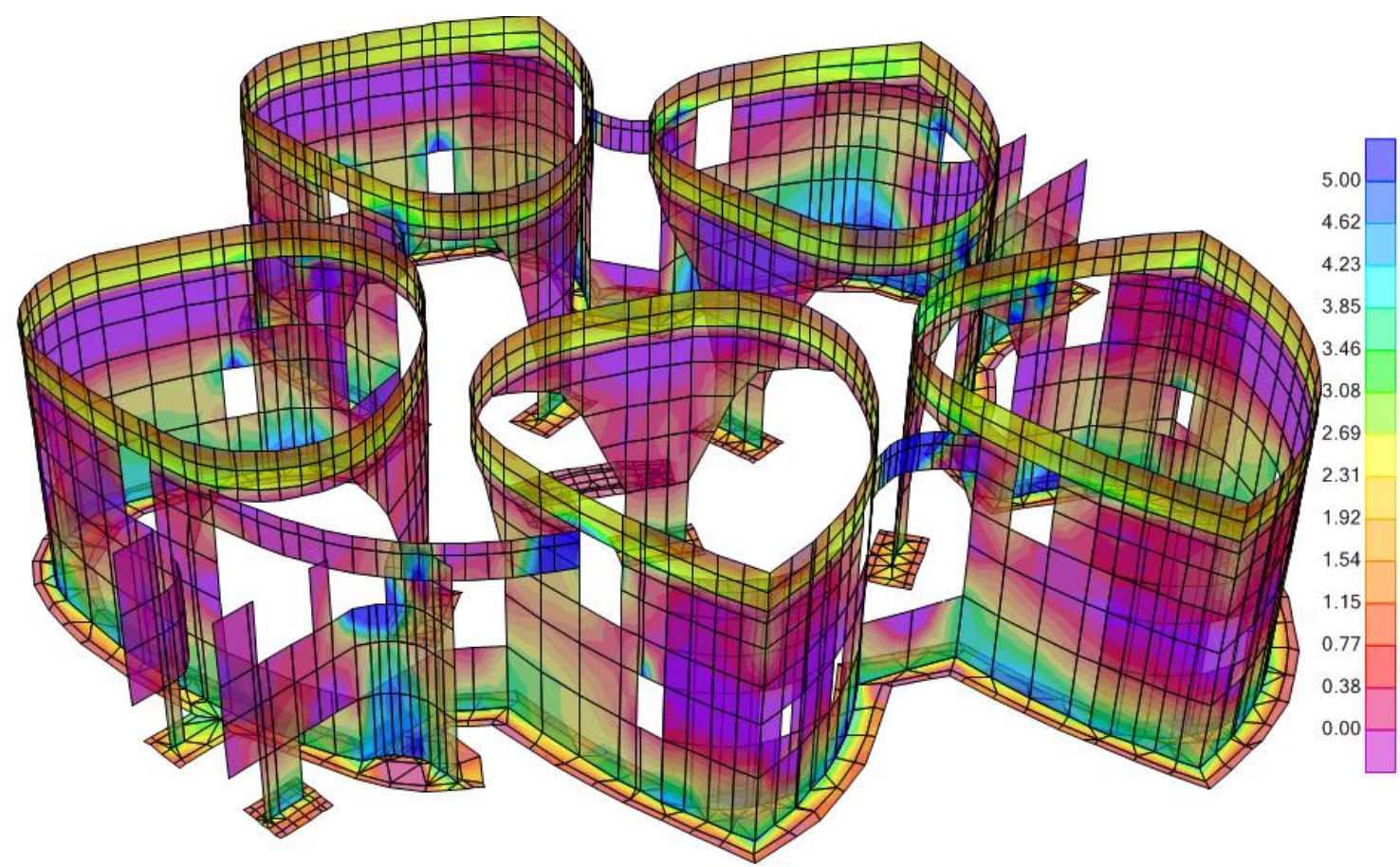

Fig. 8 Maximum Shrinkage Stresses (End of Construction Stage 4) 


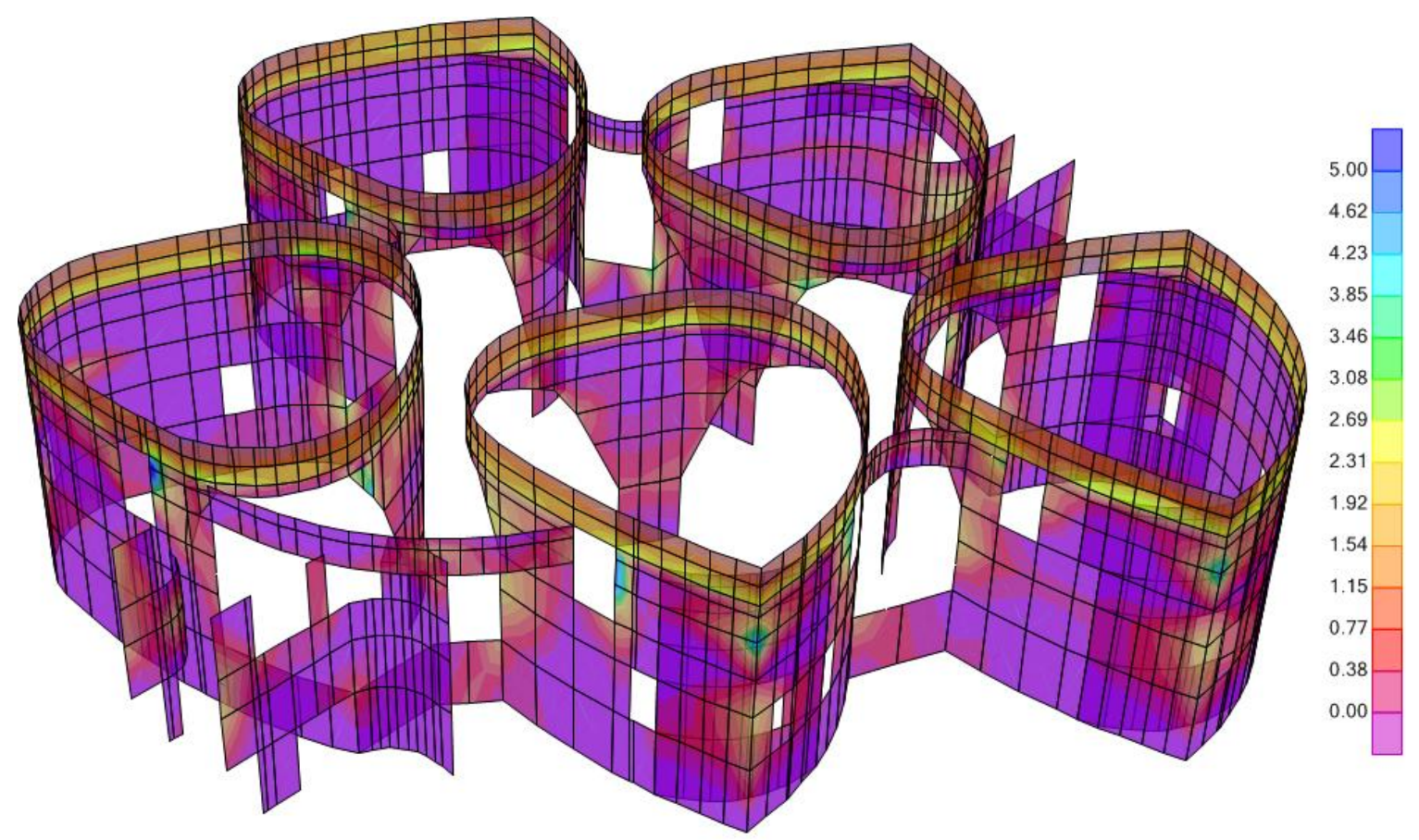

Fig. 9 Maximum Temperature Stresses

\section{Summary and Conclusions}

The risks associated with thick concrete curved walls are cracking under short-term and longterm shrinkage stresses. This paper presents the design process and analysis tools for conducting shrinkage and thermal analysis for thick concrete walls. A detailed analysis is carried out using CIRIA C660 [1] and the strain results from long term analysis are added to the short-term analysis to arrive at the total shrinkage strain and the crack-width. The results of Hot-box trials have been used in the present analysis. Furthermore, 3D analysis for longterm shrinkage and seasonal temperature variations is also carried out using SAP2000 and CEB-FIP model. Analysis assumes that the curved concrete walls are constructed in three stages from ground floor to underside of ring beam, followed by construction of ring beam. Areas of high stress identified from this analysis and adequate reinforcement provided to limit crack-width to $0.2 \mathrm{~mm}$.

\section{References}

[1] Dhir, R.K., Paine, K.A. and Zheng, L., "Design data for low heat and very low heat special cements", University of Dundee, Research Contract No. CTU/153), Report CTU/4006, 2006.

[2] British Standards Institution, Eurocode 2 "Design of Concrete Structures - Part 3: Liquid retaining and containment structures, EN 1992-3:2006.

[3] Concrete Society, "Movement restraint and cracking in concrete structures", Technical Report 67, 2008.

[4] Bamforth, P.B., "Early-age thermal crack control in concrete", CIRIA Report C660, Construction Industry Research and Information, London, 2007.

[5] CEB-FIP Model Code 1990: Design Code, "Comite Euro - International De Beton", Thomas Telford, 1991. 